\title{
Realizacja zrównoważonej gospodarki leśnej w wymiarze lokalnym, regionalnym i globalnym - wybrane aspekty prawne
}

1. Problematyka gospodarowania zasobami środowiska jest niezwykle rozległa. Jednym z jej obszarów jest gospodarka leśna, wyodrębniona przez ustawodawcę ze względu na jej przedmiot - lasy. „Gospodarka leśna” jest terminem języka prawnego, zdefiniowanym w przepisach ustawy o lasach ${ }^{1}$. Postacią kwalifikowaną tego pojęcia, a zarazem podstawową kategorią pojęciową w ustawie o lasach, jest „trwale zrównoważona gospodarka leśna”². W literaturze wskazuje się, że termin ,gospodarka” oznacza „całość mechanizmów i warunków działania podmiotów gospodarczych związanych z wytwarzaniem i podziałem dóbr i usług; gospodarowanie, dysponowanie, zarządzanie"’.

Prawna regulacja gospodarki leśnej należy do kompetencji państw członkowskich Unii Europejskiej, co jednak nie oznacza, że zależy ona wyłącznie od uwarunkowań krajowych ${ }^{4}$. Przeciwnie, gospodarka leśna pozostaje pod wpływem różnych czynników w wymiarze lokalnym i globalnym, na wielu płaszczyznach. W szczególności w sferze lokalnej podlega ścisłej regulacji prawnej w zakresie planowania, urządzania lasu, pozyskania drewna.

${ }^{1}$ Art. 6 ust. 1 ustawy o lasach z 28 września 1991 r., t.j. Dz.U. z 2017 r. poz. 788 ze zm., dalej zwana ,ustawą o lasach".

2 Art. 6 ust. 1 pkt. 1 a ustawy o lasach.

3 Por. np. B. Rakoczy, Pojęcie gospodarowania zasobami środowiska w: B. Rakoczy, M. Szalewska, K. Karpus (red.), Prawne aspekty gospodarowania zasobami środowiska, Torun 2014, s. 25.

${ }^{4} \mathrm{Na}$ temat uwarunkowań prawnych gospodarki leśnej w perspektywie prawa unijnego zob. więcej: J. Goździewicz-Biechońska, K. Leśkiewicz, Prawnoeuropejskie uwarunkowania gospodarki leśnej w: P. Litwiniuk (red.), Integracja europejska jako determinanta polityki wiejskiej. Aspekty prawne, Warszawa 2017, s. 223-235. 
Sprzedaż drewna podlega natomiast polityce handlowej Unii Europejskiej ${ }^{5}$. W kontekście globalnym największy wpływ na realizację gospodarki leśnej mają zwłaszcza zagrożenia dla środowiska, różnorodności biologicznej, zmiany klimatyczne i ukształtowane wskutek ujawnionych problemów idee oraz koncepcje recypowane w ustawodawstwie. W szczególności wskazać należy zasadę zrównoważonego rozwoju, która zdeterminowała rozwiązania o charakterze systemowym w politykach, strategiach i regulacjach prawnych ${ }^{6}$. W prawie Unii Europejskiej nie wprowadzono jednolitych rozwiązań prawnych, które obowiązywałyby w zakresie efektów osiąganych w procesie realizacji gospodarki leśnej we wszystkich państwach członkowskich, choć w niektórych ustawodawstwach stosuje się podejście oparte na dobrych praktykach ${ }^{7}$. Wskazane uwarunkowania nasuwają pytanie, w jaki sposób i według jakich kryteriów należy oceniać, czy realizowana gospodarka leśna jest rzeczywiście „trwale zrównoważona”?

Zagadnienie określone w tytule niniejszego opracowania nie było dotychczas poruszane w literaturze prawniczej, choć pojęcie gospodarki leśnej cieszy się zainteresowaniem - głównie przedstawicieli nauki prawa ochrony środowiska ${ }^{8}$. Za podjęciem się opracowania niniejszej tematyki przemawiają zwłaszcza względy społeczno-gospodarcze oraz teoretyczne.

Gdy chodzi o te pierwsze - wskazać należy, że Polska jako producent mebli zajmuje 10 miejsce, a jako eksporter mebli - 4 miejsce na świecie ${ }^{9}$. Sprzedaż drewna stanowi więc ważny element realizacji funkcji lasów ${ }^{10}$. $\mathrm{Z}$ tych przy-

${ }^{5} \mathrm{Na}$ temat polityki handlowej zob. bliżej M. Czermińska, Zasady i funkcjonowanie wspólnej polityki handlowej Unii Europejskiej - implikacje dla Polski, „Zeszyty Naukowe Uniwersytetu Ekonomicznego w Krakowie" 2008, nr 777, s. 5-30, https://r.uek.krakow.pl/bitstream/123456789/1371/1/159655573.pdf [dostęp: 20.05.2018].

${ }^{6}$ Por. art. 5 Konstytucji Rzeczypospolitej Polskiej z 2 kwietnia 1997 r., Dz.U. 78 poz. 483.

7 Por. art. 14 b ust. 2 ustawy o lasach oraz rozporządzenie Ministra Środowiska z 18 grudnia 2017 r. w sprawie wymagań dobrej praktyki w zakresie gospodarki leśnej, Dz.U. z 2017 r. poz. 2408.; Por. np. Code of Best Forest Practice - Ireland, Forest Service Department of the Marine and Natural Resources, Dublin 2000, s.20-22, https://www.agriculture.gov.ie/media/migration/forestry/publications/codeofbestforestpractice/Code $\% 20$ of $\% 20$ Best $\% 20$ Forest $\% 20$ Prac $\% 20$ Part\%201.pdf [dostęp: 17.07.2017].

${ }^{8}$ Por. A. Habuda, W. Radecki, Rozdziat 7. Trwale zrównoważona gospodarka leśna w: A. Habuda (red.), Polskie prawo leśne, Warszawa 2016, s. 166-196; J. Pakuła, Pojęcie i zasady gospodarki leśnej w: B. Rakoczy (red.), Wybrane problemy prawa leśnego, Warszawa 2011, s. 79 i n.

9 Dane dotyczą 2012 roku i pochodzą z portalu http://www.lasy.gov.pl/pl/drewno/polski-przeboj [dostęp: 13.05.2018]. Z kolei według danych na stronie http://www.drema.pl/pl/news/ eksport_polskich_wyrobow_z_drewna/ [dostęp: 13.05.2018], w rankingu europejskim Polska zajmuje pierwsze miejsce w produkcji podłóg, drugie - w produkcji europalet, drudzy drugie w produkcji okien i drzwi i trzecie w produkcji mebli.

${ }^{10}$ Por. W. Lis, Najważniejsze czynniki wpływajace na sytuację przemysłu drzewnego $w$ Polsce w 2012 roku, ,Transfer Innowacji” 2012, nr 23, s. 207 i n., https://www.sjf.tuke.sk/transferinovacii/ 
czyn dostarczanie na rynek surowca wysokiej jakości pozwala osiągać gospodarcze efekty i lokuje sektor leśno-drzewny na ważnej pozycji w gospodarce narodowej. Jednocześnie nabywcy drewna chcą mieć pewność, że surowiec nie był pozyskiwany ze szkodą dla środowiska. Wskazuje się, że konsumenci na świecie uważają, że bardzo ważne jest dokonywanie wyborów etycznych, a $60 \%$ z nich uważa, że ich decyzja o zakupie produktu oznaczonego etykietą wskazującą na sposób pozyskania drewna może wywrzeć pozytywny wpływ na lasy na świecie ${ }^{11}$.

Podjęcie tej tematyki ze względów teoretycznych opiera się na przekonaniu, że pojęcie zrównoważonej gospodarki leśnej analizować należy w perspektywie choćby Nowej strategii leśnej UE na rzecz lasów i sektora leśno-drzewnego ${ }^{12}$ czy Agendy na rzecz zrównoważonego rozwoju z 23 września 2015 r., gdzie występuje odwołanie do zrównoważonego korzystania i zarządzania zasobami leśnymi ${ }^{13}$.

Czy, a jeśli tak, to w jaki sposób ustawodawca kształtuje pozyskiwanie surowca drzewnego w sposób odpowiadający pojęciu trwale zrównoważonej gospodarki leśnej? Struktura artykułu została podporządkowana odpowiedzi na to pytanie. Najpierw uwagę poświęcę pojęciu trwale zrównoważonej gospodarki leśnej, a następnie uwarunkowaniom jej realizacji w sferze lokalnej, regionalnej i globalnej.

Ramy artykułu pozwalają jedynie zasygnalizować niektóre, wybrane kierunki rozważań, a więc niniejsze opracowanie nie wyczerpuje poruszanej problematyki.

2. Gospodarka leśna oznacza „działalność leśną w zakresie urządzania, ochrony i zagospodarowania lasu, utrzymania i powiększania zasobów i upraw leśnych, gospodarowania zwierzyną, pozyskiwania - z wyjątkiem skupu drewna, żywicy, choinek, karpiny, kory, igliwia, zwierzyny oraz płodów runa

pages/archiv/transfer/23-2012/pdf/207-212.pdf [dostęp: 20.05.2018].

${ }^{11}$ Zob. więcej https://www.pefc.pl/nowosci/nowosci/247-konsumenci-maja-zaufanie-do-etykiet-certyfikacyjnych [dostęp: 13.05.2018].

${ }^{12}$ Dokument pn. Komunikat Komisji Komunikat Komisji do Parlamentu Europejskiego, Rady, Europejskiego Komitetu Ekonomiczno-Społecznego i Komitetu Regionów Nowa strategia leśna UE na rzecz lasów i sektora leśno-drzewnego /* COM/2013/0659 final */, http://eur-lex.europa. eu/legal-content/PL/TXT/?uri=CELEX\%3A52013DC0659 [dostęp: 05.08.2017].

${ }_{13}$ Rezolucja przyjęta przez Zgromadzenie Ogólne ONZ w dniu 25 września 2015 r. [bez odniesienia do Komitetu Głównego (A/70/L.1)] 70/1. Przekształcamy nasz świat: Agenda na rzecz zrównoważonego rozwoju 2030, http://www.unic.un.org.pl/files/164/Agenda\%202030_pl_2016_ ostateczna.pdf [dostęp: 29.04.2018]. Szerzej na ten temat: U. Kurczewska, Rola Unii Europejskiej $w$ zarządzaniu globalnymi dobrami publicznymi w ramach polityki zrównoważonego rozwoju w: E. Latoszek, M. Proczek, M. Krukowska (red.), Zrównoważony rozwój a globalne dobra publiczne w teorii i praktyce organizacji międzynarodowych, Warszawa 2016, s. 157 i n. 
leśnego, a także sprzedaż tych produktów oraz realizację pozaprodukcyjnych funkcji lasu"14.

Natomiast wyrażenie „trwale zrównoważonej gospodarki leśnej” oznacza „działalność zmierzającą do ukształtowania struktury lasów i ich wykorzystania w sposób i w tempie zapewniającym trwałe zachowanie ich bogactwa biologicznego, wysokiej produkcyjności oraz potencjału regeneracyjnego, żywotności i zdolności do wypełniania, teraz i w przyszłości, wszystkich ważnych ochronnych, gospodarczych i socjalnych funkcji na poziomie lokalnym, narodowym i globalnym, bez szkody dla innych ekosystemów"15. Chodzi zatem o to, by realizowana gospodarka nie miała charakteru wyczerpującego zasoby, lecz służyła zachowaniu wartości lasów na przyszłość. W literaturze wskazuje się, że ustawodawca zamiennie używa terminów: ,gospodarowanie” i ,gospodarka” w odniesieniu do poszczególnych zasobów środowiska ${ }^{16}$.

Jak widać, pojęcie gospodarki leśnej skupia się na „działalności” ${ }^{17}$. W treści przywołanego pojęcia chodzi o działalność, która ma zmierzać do osiągnięcia określonego w nim stanu polegającego zwłaszcza na ukształtowaniu struktury lasów i ich wykorzystania w sposób i w tempie zapewniającym trwałe zachowanie określonych przez prawodawcę cech na poziomie lokalnym, narodowym i globalnym, bez szkody dla innych ekosystemów. Nie bez znaczenia jest także kolejność wymienionych celów ${ }^{18}$.

W przywołanym pojęciu prawodawca nawiązuje do zasady zrównoważonego rozwoju ${ }^{19}$, co odpowiada wymogowi, by gospodarowanie strategicznymi zasobami naturalnymi, którymi są lasy państwowe, było prowadzone zgodnie $\mathrm{z}$ zasadą zrównoważonego rozwoju w interesie dobra ogólnego ${ }^{20}$. Zasada zrównoważonego rozwoju określona w art. 5 Konstytucji RP oznacza konieczność znajdowania takich rozwiązań technicznych, organizacyjnych, prawnych itp., sprzyjających rozwojowi ekonomicznemu, czy szerzej, cywilizacyjnemu, które pozwolą chronić środowisko naturalne, przy czym odnosi się to zarówno do stanowienia, jak i stosowania prawa ${ }^{21}$. Gospodarka leśna ma udział w zacho-

${ }^{14}$ Art. 6 ust. 1 pkt. 1 ustawy o lasach.

${ }_{15}$ Art. 6 ust. 1 pkt 1a ustawy o lasach.

16 Por. np. B. Rakoczy, Pojęcie gospodarowania zasobami środowiska, op.cit., s. 25.

17 Ibidem, s. 27.

${ }_{18}$ M. Walas, Korzystanie z lasów a trwale zrównoważona gospodarka leśna w: B. Rakoczy (red.), Wybrane problemy prawa leśnego, Warszawa 2011, s. 96-117.

19 Por. W. Radecki, Ustawa o lasach Komentarz, LEX.

${ }^{20}$ Art. 3 ustawy o zachowaniu narodowego charakteru strategicznych zasobów naturalnych kraju z dnia 6 lipca 2001 r., Dz.U. z 2001 r. nr 97 poz. 1051, dalej zwanej ustawą o zachowaniu narodowego charakteru zasobów.

${ }^{21}$ B. Banaszak, Konstytucja Rzeczypospolitej Polskiej. Komentarz. Wyd. 2, Warszawa 2012, Legalis. 
waniu równowagi ekologicznej kraju ${ }^{22}$. Zatem stwierdzić wypada, że realizacja gospodarki leśnej zgodnie z zasadą zrównoważonego rozwoju jest prawnym obowiązkiem podmiotów, które ją realizują.

Koncepcja zrównoważonego rozwoju, jak wskazują przedstawiciele nauk ekonomicznych, opiera się na „dążeniu do osiągnięcia jak najlepszego wyniku ekonomicznego przy jednoczesnym poszanowaniu ochrony środowiska naturalnego oraz rozwoju społecznego", albo, według innej definicji powoływanej za E. Latoszek, jest to „trwała poprawa jakości życia współczesnych i przyszłych pokoleń poprzez kształtowanie właściwych proporcji między trzema rodzajami kapitału: ekonomicznym (E), ludzkim (L) i przyrodniczym"23. A. Graczyk wskazuje jednak, że ,podstawą oceny miejsca lasów i gospodarki leśnej w strategii wzrostu gospodarczego oraz rozwoju zrównoważonym jest rozróżnienie między dwoma sposobami podejścia do procesów dynamiki gospodarki - wzrostem i rozwojem"24.

Należy podkreślić, że zasada zrównoważonego rozwoju wywodzi się z potrzeby ochrony środowiska, w efekcie czego powstały odpowiednie instytucje i przyjęto szereg aktów - konwencji na szczeblu międzynarodowym ${ }^{25} \mathrm{i}$ unijnym, rzutujących na sposób prowadzenia gospodarki leśnejej. Wspomnieć należy także publikacje z międzynarodowych konferencji, np. II Konferencji w Rio de Janeiro $^{27}$. Pojęcie zrównoważonego rozwoju zdefiniowano jako ,proces mający na celu zaspokojenie aspiracji rozwojowych obecnego pokolenia, w sposób umożliwiający realizację tych samych dążeń następnym pokoleniom"28.

Warto w tym miejscu zwrócić uwagę na aspekty terminologiczne i związane $\mathrm{z}$ nimi kwestie thumaczenia wyrażenia sustainable development na język polski.

22 Tak, np. P. Paschalis-Jakubowicz, Uwarunkowania strategii rozwoju Lasów Państwowych, Warszawa 2012, s. 7.

${ }^{23}$ E. Latoszek, Koncepcja zrównoważonego rozwoju w teorii i praktyce ONZ w: E. Latoszek, M. Proczek, M. Krukowska (red.), Zrównoważony rozwój a globalne dobra publiczne w teorii i praktyce organizacji międzynarodowych, Warszawa 2016, s. 25 i przywołana tam literatura.

${ }^{24}$ A. Graczyk, Lasy oraz gospodarka leśna w strategii wzrostu gospodarczego i rozwoju zrównoważonym w: Konferencja naukowa. Polskie lasy i leśnictwo w Europie. Kraków Uniwersytet Jagielloński 29 listopada 2004 r., Warszawa 2005, s. 85.

${ }^{25}$ United Nations Conference on the Human Environment (Stockholm Conference) June 5-16, 1972 https://sustainabledevelopment.un.org/milestones/humanenvironment, dostęp 7 lipca 2017 r.; Report of the World Commission on Environment and Development: Our Common Future, https://sustainabledevelopment.un.org/content/documents/5987our-common-future.pdf [dostęp: 07.07.2017]; Transforming our world: the 2030 Agenda for Sustainable Development http://www. un.org/ga/search/view_doc.asp?symbol=A/RES/70/1\&Lang=E [dostęp: 07.07.2017].

${ }^{26}$ E. Latoszek, Koncepcja zrównoważonego rozwoju ..., s. 26 i przywołana tam literatura.

27 Ibidem s. 27, 28 i przywołana tam literatura.

${ }^{28}$ W 1987 roku ukazał się raport Światowej Komisji Środowiska i Rozwoju ONZ, obradującej pod przewodnictwem Gro Harlem Brundtland, pt. „Nasza wspólna przyszłość”, http://www.unesco.pl/edukacja/dekada-edukacji-nt-zrownowazonego-rozwoju/unesco-a-zrownowazony-rozwoj/ [dostęp: 07.07.2017]. 
Początkowo wśród określeń, jakie miały oddawać sens tego sformułowania, wskazywano „rozwój zrównoważony” oraz „rozwój trwały”, których znaczenie nie jest tożsame, albowiem, jak wskazuje K. Górka, wyrażenie „rozwój trwały” zapewnia zwłaszcza odpowiedni stan środowiska i równowagę ekologiczną i jest przeciwieństwem „stanu zerowego wzrostu”, a zatem pojęcia „rozwoju trwałego" i ,rozwoju zrównoważonego" różnią się ${ }^{29}$.

W szczególności realizacja zrównoważonej gospodarki leśnej wpisuje się w najbardziej aktualne na arenie międzynarodowej podejście do gospodarowania zasobami naturalnymi we wspomnianej Agendzie na rzecz zrównoważonego rozwoju ${ }^{30}$. Zatem kształtowanie przez państwa gospodarki leśnej w krajowych regulacjach prawnych wymaga uwzględnienia uwarunkowań międzynarodowych w realizacji gospodarki leśnej oraz obrotu drewnem ${ }^{31}$.

3. Gdy chodzi o sposób zapewniania realizacji gospodarki leśnej zgodnie z zasadą zrównoważonego rozwoju wskazać należy, że prawodawstwo unijne koncentruje się na przeciwdziałaniu nielegalnemu pozyskaniu drewna ${ }^{32}$. Przepisom prawa Unii Europejskiej w ramach polityki handlowej podlega przywóz drewna na rynek wewnętrzny ${ }^{33}$ oraz obowiązki podmiotów wprowadzających drewno i produkty $z$ drewna do obrotu ${ }^{34}$. Prawodawca nakłada na kraje członkowskie wiele obowiązków związanych z przeciwdziałaniem nielegalnemu pozyskaniu drewna, wynikających z przepisów rozporządzeń nr 2173/2005 35

${ }^{29}$ K. Górka, Wdrażanie koncepcji rozwoju zrównoważonego w: M. Burchard-Dziubińska, A. Rzeńca (red.), Zrównoważony rozwój na poziomie lokalnym i regionalnym. Teoria i praktyka, Łódź 2010, s. 10 i n.

${ }^{30}$ Rezolucja przyjęta przez Zgromadzenie Ogólne w dniu 25 września 2015 r. [bez odniesienia do Komitetu Głównego (A/70/L.1)] 70/1. Przekształcamy nasz świat: Agenda na rzecz zrównoważonego rozwoju 2030, http://www.unic.un.org.pl/files/164/Agenda\%202030_pl_2016_ostateczna. pdf [dostęp: 29.04.2018].

${ }^{31}$ Rozporządzenie Rady (WE) nr 2173/2005 z dnia 20 grudnia 2005 r. w sprawie ustanowienia systemu zezwoleń na przywóz drewna do Wspólnoty Europejskiej FLEGT, Dz.Urz. UE L 347 z 30.12.2005, str. 1, z późn. zm., zwanego dalej „,rozporządzeniem nr 2173/2005”; Rozporządzenie Parlamentu Europejskiego i Rady (UE) nr 995/2010 z dnia 20 października 2010 r. ustanawiającego obowiązki podmiotów wprowadzających do obrotu drewno i produkty z drewna, Dz.Urz. UE L 295 z 12.11.2010, str. 23, zwanego dalej ,rozporządzeniem nr 995/2010”.

${ }_{32}$ Zob. bliżej K. Leśkiewicz, Administracyjne kary pieniężne związane z wprowadzaniem do obrotu nielegalnie pozyskanego drewna i produktów z drewna, „Studia Iuridica Agraria” 2017, tom XV, s. 105 i n.

${ }^{33}$ Rozporządzeniem nr 2173/2005.

34 Rozporządzenie nr 995/2010.

${ }^{35}$ Przez „legalnie produkowane drewno” należy rozumieć „produkty z drewna wykonane z krajowego drewna, którego wyrąb był legalny lub z drewna legalnie przywiezionego do państwa partnerskiego zgodnie z przepisami krajowymi tego państwa partnerskiego określonymi w umowie o partnerstwie", zgodnie z art. 2 pkt. 10 rozporządzenia nr 2173/2005. Drewnem 
oraz 995/2010 ${ }^{36}$. Zasadniczo chodzi o realizację zakazu wprowadzania do obrotu nielegalnie pozyskanego drewna i związanych z tym niekorzystnych zjawisk społecznych, ekonomicznych, przyrodniczych. Drewno nielegalnie pozyskane oznacza drewno pozyskane $\mathrm{z}$ naruszeniem mającego zastosowanie ustawodawstwa kraju pozyskania ${ }^{37}$, a więc m.in. ustawy o lasach. Ustawa o lasach nie określa wprost konkretnego obowiązku w postaci nakazu prowadzenia gospodarki leśnej trwale zrównoważonej ani zgodnie z zasadą zrównoważonego rozwoju. Przepisy ustawy o lasach stanowią w tym względzie, że trwale zrównoważoną gospodarkę leśną prowadzi się według planu urządzenia lasu lub uproszczonego planu urządzenia lasu, z uwzględnieniem celów wskazanych w art. 7 ustawy o lasach. Dopiero przepisy ustawy o zachowaniu narodowego charakteru strategicznych zasobów naturalnych nakazują, by gospodarowanie nimi było zgodne z zasadą zrównoważonego rozwoju „w interesie dobra ogólnego" 38 .

Prawodawca dostrzega, że nielegalne pozyskiwanie drewna jest powszechnym problemem o znaczeniu międzynarodowym, albowiem powoduje proces wylesiania i degradacji lasów, będącego przyczyną około $20 \%$ światowych emisji $\mathrm{CO}_{2}$, zagraża różnorodności biologicznej i szkodzi zrównoważonej gospodarce leśnej oraz rozwojowi lasów, a także opłacalności rynkowej podmiotów działających zgodnie z mającym zastosowanie ustawodawstwem ${ }^{39}$. Nadto wspomniane zjawisko przyczynia się do pustynnienia i erozji gleby, a także wywołuje niepożądane skutki społeczne, polityczne i gospodarcze.

Rozwiązania prawne służą kontroli i nadzorowi nad wprowadzaniem drewna i produktów z drewna do obrotu. Zamiarem ustawodawcy jest stworzenie odpowiednich „narzędzi” służących zmniejszeniu zużycia nielegalnie pozyskanego drewna, jak również przyczyniających się do osiągnięcia celu, jakim jest zrównoważona gospodarka zasobami leśnymi w państwach produkujących drewno ${ }^{40}$. Utworzenie systemu zezwoleń ma więc służyć zapewnieniu, że na teren Unii Europejskiej będą przywożone wyłącznie produkty z drewna, które zostało pozyskane legalnie, zgodnie z prawem krajowym państwa produkującego drewno ${ }^{41}$. System zezwoleń w zakresie egzekwowania prawa, zarządzania i handlu w dziedzinie leśnictwa nazywany „systemem zezwoleń FLEGT” oznacza

nielegalnie pozyskanym będzie więc drewno pozyskane poprzez wyrąb niezgodny z prawem kraju, w którym je pozyskano, lub takie, którego przywóz był niezgodny z prawem kraju, z którego je przywieziono.

${ }^{36}$ Nielegalnie pozyskane drewno oznacza pozyskane z naruszeniem mającego zastosowanie ustawodawstwa kraju pozyskania według art. 2 lit. g rozporządzenia nr 995/2010.

${ }_{37}$ Art. 2 lit. g rozporządzenia $\mathrm{nr}$ 995/2010.

${ }^{38}$ Art. 3 ustawy o zachowaniu narodowego charakteru zasobów.

${ }^{39}$ Pkt. 3 preambuly do rozporządzenia $\mathrm{nr}$ 995/2010.

${ }^{40}$ Pkt 2 preambuły do rozporządzenia $\mathrm{Nr}$ 2173/2005.

${ }^{41}$ Pkt 3 preambuly do rozporządzenia $\mathrm{Nr}$ 2173/2005. 
wydawanie zezwoleń na wywóz produktów z drewna z państw partnerskich do Wspólnoty oraz wdrożenie tego systemu we Wspólnocie, w szczególności jego przepisów dotyczących kontroli granicznych ${ }^{42}$.

Przez termin „przywóz” ustawodawca nakazuje rozumieć „dopuszczenie produktów $z$ drewna do swobodnego obrotu w rozumieniu art. 79 rozporządzenia Rady (EWG) Nr 2913/1992 z 12.10.1992 r. ustanawiającego Wspólnotowy Kodeks Celny"³. Przywóz do Unii Europejskiej produktów z drewna wywiezionych z państw partnerskich jest zakazany, jeżeli dostawa nie jest objęta zezwoleniem FLEGT $^{44}$, $\mathrm{z}$ wyjątkiem produktów $\mathrm{z}$ drewna gatunków wymienionych $\mathrm{w}$ załącznikach A, B i C do rozporządzenia Rady (WE) Nr 338/97, które są zwolnione ze wspomnianego wymogu ${ }^{45}$. Natomiast produkty z drewna wywożone z państwa partnerskiego i wprowadzane do Unii Europejskiej przez jakikolwiek punkt celny muszą być objęte zezwoleniem tego państwa partnerskiego, stwierdzającym, że dane produkty $\mathrm{z}$ drewna zostały wykonane $\mathrm{z}$ krajowego drewna, którego wyrąb był legalny lub z drewna legalnie przywiezionego do państwa partnerskiego zgodnie z przepisami krajowymi, jak określono w odpowiedniej „umowie o partnerstwie”. Natomiast do organów państw członkowskich należy kontrolowanie, czy każda dostawa drewna objęta jest ważnym zezwoleniem przed dopuszczeniem takiej dostawy do swobodnego obrotu w Unii.

Również i w świetle rozporządzenia nr 995/2010 chodzi o zwalczanie zjawiska nielegalnego pozyskiwania drewna, stanowiącego zagrożenie dla lasów ${ }^{46}$. Obrót drewnem podlega ustanowionemu w rozporządzeniu nr 995/2010 zakazowi wprowadzania do obrotu nielegalnie pozyskanego drewna lub produktów pochodzących z takiego drewna. W przepisach rozporządzenia nr 995/2010 ustanowiony został nakaz postępowania „,z należytą starannością”, przy wprowadzaniu do obrotu drewna lub produktów z drewna. Podkreślić jednak należy, że do ich wdrożenia zobowiązany został podmiot wprowadzający materiały na rynek UE po raz pierwszy. Nakaz ten został uszczegółowiony w zestawie procedur i środków określonych jako „system zasad należytej staranności”47.

Obowiązki określone w rozporządzeniu nr 995/2010 dotyczą podmiotów sprowadzających drewno z krajów spoza Unii Europejskiej oraz handlujących tymi produktami na terenie Unii Europejskiej, a wymogi dotyczą wyrobów wymienionych w Załączniku I do Rozporządzenia, takich jak m.in.: drewno

${ }^{42}$ Art. 1 pkt 2 rozporządzenia Nr 2173/2005. Skrót "FLEGT” oznacza zgodnie z pkt. 1 preambuły rozporządzenia 21173/2005 "Forest Law Enforcement, Governance and Trade".

${ }^{43}$ Art. 2 pkt 11 rozporządzenia $\mathrm{Nr}$ 2173/2005.

${ }^{44}$ Art. 4 ust. 1 rozporządzenia $\mathrm{Nr}$ 2173/2005.

${ }^{45}$ Art. 4 ust. 3 rozporządzenia $\mathrm{Nr}$ 2173/2005.

${ }^{46}$ Pkt 3 preambuły do rozporządzenia $\mathrm{Nr} 995 / 2010$.

47 Zob. art. 4 ust. 2 oraz art. 6 rozporządzenia nr 995/2010. 
okrągłe, podkłady kolejowe, tarcice, forniry, podłogi, płyty drewnopochodne (MDF, OSB, wiórowe, pilśniowe, inne), sklejki, skrzynie i inne opakowania drewniane, beczki, gonty, ścier z drewna, papier, tektura, meble drewniane, biomasa na cele energetyczne i opałowe.

Wspomniane podmioty mają w szczególności obowiązek utrzymywania i regularnej oceny stosowanego przez siebie systemu zasad należytej staranności, z wyjątkiem sytuacji, w której dany podmiot korzysta z ,systemu zasad należytej staranności" ustanowionego przez organizację monitorującą, o której mowa w art. 8 rozporządzenia nr 995/2010. „System zasad należytej staranności” opierać się może na nadzorze i kontroli mających podstawy w prawodawstwie krajowym. Ponadto w ramach tego systemu należy zapewnić środki i procedury dostępu do informacji dotyczących dostarczania przez dany podmiot drewna lub produktów $\mathrm{z}$ drewna wprowadzanych do obrotu, w tym zezwolenie, dokumenty lub inne informacje potwierdzające, że drewno to i produkty z drewna spełniają wymogi mającego zastosowanie ustawodawstwa, a także procedury oceny ryzyka umożliwiające podmiotowi analizę i ocenę, czy istnieje ryzyko, że nielegalnie pozyskane drewno lub produkty pochodzące $\mathrm{z}$ takiego drewna zostaną wprowadzone do obrotu. Chodzi o zweryfikowanie pochodzenia wyrobów importowanych na teren UE.

Ustawodawca dopuszcza, by zapewnienie zgodności z mającym zastosowanie ustawodawstwem, obejmowało m.in. certyfikację lub systemy zweryfikowane przez strony trzecie dotyczące zgodności z mającym zastosowanie ustawodawstwem ${ }^{48}$. Zgodnie z przepisami rozporządzenia wykonawczego do rozporządzenia $\mathrm{nr} 995 / 2010^{49}$ certyfikacja lub inne systemy zweryfikowane przez strony trzecie mogą być wzięte pod uwagę w ocenie ryzyka i procedurach ograniczających ryzyko, jeżeli spełniają m.in. kryteria: odpowiadają wymogom mającego zastosowanie ustawodawstwa, przewidują odpowiednie kontrole, przewidują środki umożliwiające śledzenie drewna pozyskanego zgodnie z mającym zastosowanie ustawodawstwem oraz produktów wytworzonych $\mathrm{z}$ takiego drewna $\mathrm{w}$ dowolnym punkcie łańcucha dostaw zanim takie drewno lub produkty z drewna zostaną wprowadzone do obrotu, a także przewidują kontrole, zweryfikowane przez stronę trzecią, mające zapewnić niewprowadzanie drewna lub produktów z drewna niewiadomego pochodzenia, lub

${ }^{48}$ Art. 6 ust. 1 lit. a-c rozporządzenia nr 995/2010.

49 Art. 4 lit. a-d Rozporządzenia Wykonawczego Komisji (UE) nr 607/2012 z dnia 6 lipca 2012 r. w sprawie szczegółowych przepisów dotyczących systemu zasad należytej staranności oraz częstotliwości i charakteru kontroli organizacji monitorujących, przewidzianych w rozporządzeniu Parlamentu Europejskiego i Rady (UE) nr 995/2010 ustanawiającym obowiązki podmiotów wprowadzających do obrotu drewno i produkty z drewna, Dz.U.UE.L.2012.177.16, dalej zwane rozporządzeniem nr 607/2012. 
drewna, które nie zostało pozyskane zgodnie z mającym zastosowanie ustawodawstwem lub produktów z takiego drewna, do łańcucha dostaw. Zatem zastosowanie certyfikacji nie oznacza automatycznego wypełnienia wymogów systemu należytej staranności. Dopiero gdy również wymogi certyfikacji spełniają wspomniane kryteria, możliwe jest uznanie, iż spełniono obowiązek zapewnienia należytej staranności we wskazanym zakresie.

4. $\mathrm{W}$ praktyce zapewnienie, iż pozyskanie surowca drzewnego nastąpiło w ramach „zrównoważonej gospodarki leśnej” następuje poprzez ocenę zgodności - certyfikację. Certyfikacja obejmować może leśnictwo (gospodarkę leśną) lub łańcuch dostaw (w tym pochodzenie drewna). Jest ona realizowana przez międzynarodowe organizacje pozarządowe, do których przystępują zarządcy, właściciele lasów oraz podmioty funkcjonujące w sektorze drzewnym, producenci wyrobów drewnianych i innych produktów. Wśród wspomnianych organizacji wskazać należy zwłaszcza Programme for the Endorsement of Forest Certification Schemes - Program Zatwierdzenia Systemów Certyfikacji Leśnej - w skrócie „PEFC" 50 oraz Forest Stewardship Council (w skrócie „FSC") $)^{51}$. Prowadzona przez Państwowe Gospodarstwo Leśne Lasy Państwowe gospodarka leśna certyfikowana jest $\mathrm{w}$ dwóch wspomnianych systemach FSC oraz PEFC, na poziomie regionalnym - w zakresie regionalnych dyrekcji Lasów Państwowych ${ }^{52}$.

W ramach certyfikacji chodzi o potwierdzenie, że leśnictwo i gospodarka leśna realizowane są wedle standardów uwzględniających postulat zrównoważonej gospodarki leśnej według definicji Organizacji Narodów Zjednoczonych do spraw Wyżywienia i Rolnictwa (FAO) następującej treści:

${ }^{50}$ Według informacji podanych przez PEFC, w Polsce prace nad stworzeniem krajowych struktur, jeszcze w ramach Paneuropejskiego Systemu Certyfikacji Leśnej, podjęto w 2003 r. a inicjatorem procesu tworzenia krajowych standardów PEFC były Lasy Państwowe oraz Rada PEFC Polska. Od listopada 2003 roku Rada PEFC Polska, która działa w ramach struktur Stowarzyszenia Inżynierów i Techników Leśnictwa i Drzewnictwa (SITLiD) stała się członkiem PEFC Council. W 2009 roku, na podstawie umowy między Stowarzyszeniem Inżynierów i Techników Leśnictwa i Drzewnictwa i Instytutu Badawczego Leśnictwa (IBL) z 16 września 2009 nastąpiła zmiana afiliacji Rady PEFC Polska, zob. bliżej https://www.pefc.pl/o-pefc/pefc-polska, [dostęp: 13.05.2018].

${ }^{51} \mathrm{https} / / / \mathrm{pl}$.fsc.org/pl/o-fsc, [dostęp: 13.05.2018]. Warto wspomnieć, że FSC jest członkiem ISEAL, globalnego stowarzyszenia systemów norm społecznych i środowiskowych, do którego należą również Fairtrade, Marine Stewardship Council (MSC) i Rainforest Alliance.

${ }_{52}$ Według danych podanych przez FSC, całkowita wielkość obszarów objętych certyfikacją FSC w Polsce wynosi prawie 7 milionów ha w lasach zarządzanych przez Regionalne Dyrekcje Lasów Państwowych, przy czym certyfikat FSC posiadają: jeden las prywatny oraz wszystkie Dyrekcje, z wyjątkiem RDLP Krosno i 3 nadleśnictw RDLP Białystok: Browsk, Hajnówka, Białowieża, https://pl.fsc.org/pl/certyfikacja-fsc/certyfikacja-gospodarki-lesnej. 
Służebność i użytkowanie lasów i obszarów leśnych w sposób i w stopniu, który utrzymuje ich różnorodność biologiczną, produktywność, zdolność do regeneracji, zdrowotność i ich potencjał do spełniania, teraz i w przyszłości, odnośnych funkcji ekologicznych, gospodarczych i społecznych na szczeblu krajowym i ogólnoświatowym oraz który nie powoduje szkody w innych ekosystemach ${ }^{53}$.

Standardy - wzorce zrównoważonej gospodarki leśnej w zakresie leśnictwa stosowane przez organizacje pozarządowe nawiązują do wymogów opracowanych przez międzynarodowe i międzyrządowe organizacje, jak np. Ministerial Conference on the Protection of Forests in Europe (w skrócie $\mathrm{MCPFE}^{54}$ ), International Tropical Timber Organisation (w skrócie ITTO ${ }^{55}$ ), International Union for Conservation of Nature (w skrócie IUCN ${ }^{56}$ ), są wspierane przez 149 krajowych rządów i obejmują 85\% światowych obszarów leśnych ${ }^{57}$. Certyfikacja nastąpić może wyłącznie po pozytywnym przejściu oceny dokonywanej przez akredytowaną jednostkę certyfikującą pod kątem zgodności gospodarki leśnej ze stosowanym standardem, na który składa się zestaw zasad określających najlepsze praktyki i pomagających właścicielom oraz zarządcom lasów na świecie przyczyniać się do osiągnięcia celu zrównoważonej gospodarki leśnej w taki sam sposób ${ }^{58}$. Jak widać, standardy prywatnych organizacji nawiązują do zasady zrównoważonego rozwoju, a także prawodawstwa poszczególnych krajów.

Certyfikacja, wedle systemu PEFC łańcucha dostaw, służy potwierdzeniu, że produkty zawierające surowce leśne dostarczają informacji o pochodzeniu tych produktów z lasów zarządzanych w sposób trwały i zrównoważony, z recyklingu oraz z innych niekontrowersyjnych źródeł, a także wymagania dotyczące zdrowia, bezpieczeństwa i pracy ${ }^{59}$. Z kolei w certyfikacji, według FSC, chodzi o zaświadczenie, że drewno kontrolowane spełnia wymogi dwóch głównych standardów dla drewna kontrolowanego $\mathrm{FSC}^{60}$. Z certyfikacji łańcucha dostaw

${ }^{53}$ https://www.pefc.pl/jak-uzyskac-certyfikat/certyfikacja-lesnictwa [dostęp: 13.05.2018].

${ }^{54} \mathrm{http}: / /$ forestportal.efi.int/view.php?id=1895\&c=E1 [dostęp: 13.05.2018].

${ }^{55} \mathrm{http} / / / \mathrm{www} . \mathrm{itto} . \mathrm{int} / \mathrm{partner} / \mathrm{id}=1918$ [dostęp: 13.05.2018].

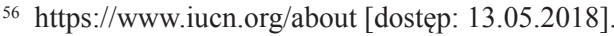

57 Por. dokument Norma krajowa PEFC PEFC PL 1003:2012, Grudzień 2012, Zrównoważona gospodarka leśna - wymagania, https://www.pefc.pl/images/PEFC_PL_1003v.2-pol_final. pdf [dostęp: 13.05.2018].

${ }_{58}$ Zob. Zasady i kryteria FSC, International Generic Indicators FSC-STD-60-004 V1-0 EN http://igi.fsc.org/approved-documents.60htm, [dostęp: 13.05.2018].

59 Por. Międzynarodowa norma PEFC, PEFC ST 2002:2013, Wymagania dla użytkowników systemu PEFC Tłumaczenie polskie, 245.2013, Łańcuch dostaw wyrobów zawierających surowce leśne - wymagania, https://www.pefc.pl/images/dokumenty/pefc-st-2002-2013pl.pdf [dostęp: 13.05.2018].

${ }^{60}$ FSC-STD-40-005 V3-1 FSC Wymogi dotyczące pozyskiwania Drewna Kontrolowanego FSC - Standard ten ma na celu zapewnienie, że firmy będą unikać pozyskiwania materiału 
korzystać mogą przedsiębiorcy branży drzewnej, papierniczej, handlu pośredników czy drukarni, wydawnictw itp.

5. Na szczeblu lokalnym - krajowym, ze wspomnianym zakazem wprowadzania do obrotu nielegalnie pozyskanego drewna, wiążą się obowiązki państw członkowskich w zakresie zapewnienia, by sankcje za naruszenie przepisów rozporządzeń nr 995/2010 oraz 2173/2005 były „,skuteczne, proporcjonalne i odstraszające". Przepisy sankcjonujące zakazy określone wspomnianą wyżej regulacją prawa Unii Europejskiej zawarte są w art. 66a-66i ustawy o lasach. Zgodnie z tytułem rozdziału 9a ustawy o lasach, są to ,administracyjne kary pieniężne". Chodzi zatem o zapewnienie na różnych szczeblach wykonawstwa efektywności unijnego prawa, delimitującej zakres krajowej autonomii instytucjonalnej i proceduralnej ${ }^{61}$, a także cechy sankcji wskazane w prawodawstwie unijnym. Muszą one bowiem realizować cele unijnych rozporządzeń, zwłaszcza zapewniać możliwość egzekwowania zakazu wprowadzania do obrotu nielegalnego drewna i tym samym urzeczywistniać realizację gospodarki leśnej z zasadą zrównoważonego rozwoju.

6. Realizacja gospodarki leśnej pozostaje pod silnym wpływem uwarunkowań globalnych, związanych z potrzebą ochrony środowiska, z których wywodzi się zasada zrównoważonego rozwoju. Na szczeblu regionalnym ustawodawca określił ,środki” służące przeciwdziałaniu wprowadzania do obrotu drewna pozyskanego nielegalnie. Chodzi o wkomponowaną w unijny „system zasad należytej staranności" zasadę śledzenia produktów - drewna i pochodnych (traceability), zasadę zarządzania ryzykiem opartą na informacji i ocenie ryzyka w całym łańcuchu dostaw drewna i produktów pochodnych określonych w przepisach wskazanych rozporządzeń, a więc na ścieżce ,z lasu do finalnego nabywcy".

Na szczeblu lokalnym instrumentami mającymi realizować wskazany wyżej cel zrównoważonej gospodarki leśnej są kontrola, nadzór oraz sankcje za naruszenie wymogów rozporządzeń nr 995/2010 oraz nr 2173/2005. Ustawodawca nie reguluje jednak prawnych standardów prowadzenia „trwale zrów-

z nieakceptowanych źródeł; FSC-STD-30-010 V2-0 Zasady gospodarki leśnej dla certyfikacji Drewna Kontrolowanego FSC. Określa on wymogi dla podmiotów prowadzących gospodarkę leśną, dotyczące stosowania praktyk zarządzania gwarantujących pozyskiwanie materiału z akceptowanych źródeł, dostępne na stronie https://pl.fsc.org/pl/certyfikacja-fsc/drewno-kontrolowane [dostęp: 13.05.2018].

${ }^{61}$ Por. M. Niedźwiedź, Pośrednie wykonywanie prawa UE przez administrację $R P \mathrm{w}$ : R. Hauser, A. Wróbel, Z. Niewiadomski (red.), Europeizacja prawa administracyjnego. System Prawa Administracyjnego. Tom 3, wyd. 1, Legalis 2014. 
noważonej gospodarki leśnej”, lecz wskazuje możliwe sposoby weryfikacji i oceny jej realizacji (w tym certyfikację), które muszą jednak spełniać założenia właściwego krajowego ustawodawstwa. Jednym z istotnych pod względem praktycznym sposobów wypełnienia wymogów systemu zasad należytej staranności jest certyfikacja gospodarki leśnej i łańcucha dostaw produktów pod kątem zgodności z zasadą zrównoważonego rozwoju prowadzona przez organizacje o zasięgu międzynarodowym. Należy zatem stwierdzić, że w praktyce o sposobie realizacji zasad systemu należytej staranności ostatecznie przesądzają praktyki rynkowe i związane z nimi globalne systemy oceny zgodności, nawiązujące do krajowego prawodawstwa w zakresie leśnictwa.

\title{
IMPLEMENTATION OF SUSTAINABLE FOREST MANAGEMENT AT LOCAL, REGIONAL AND GLOBAL LEVEL - SELECTED LEGAL ASPECTS
}

\section{Sum mary}

The aim of the article is to answer the question whether and if so, how the legislator shapes the harvesting of timber in a manner consistent with the objectives of sustainable forest management. The implementation of forest management is strongly influenced by global conditions. At the regional level, the legislator has defined "measures" implemented to counteract the marketing of illegally harvested timber. They are known as the EU's "due diligence system" used in the timber supply chain "from forest to final purchaser." At the local level, the instruments to achieve this objective of sustainable forest management include control, supervision and sanctions for breaches of Regulations 995/2010 and 2173/2005, while in practice, it is global market practices and related global conformity assessment systems relating to national forestry legislation that ultimately determine how the principles of the due diligence system will be implemented.

\section{L'ATTUAZIONE DELLA GESTIONE FORESTALE SOSTENIBILE TRA LOCALE, REGIONALE E GLOBALE - ASPETTI GIURIDICI SCELTI}

\author{
Riassunto
}

L'articolo si propone di rispondere alla domanda se e, in caso di risposta affermativa, in che modo il legislatore influenzi l'andamento dell'approvvigionamento delle materie prime legnose a seconda degli obiettivi della gestione forestale sostenibile. L'attuazione della gestione forestale rimane sotto una forte influenza delle condizioni globali. A livello regionale, il legislatore ha definito "misure" volte a contrastare la commercializzazione di legno di provenienza illegale. Si tratta di un sistema di „dovuta diligenza” adottato nella catena di approvvigionamento del legno, "dalla foresta al compratore finale". A livello 
locale, gli strumenti per raggiungere l'obiettivo della gestione in questione sono il controllo, la supervisione e le sanzioni previste per la violazione dei requisiti dei regolamenti $995 / 2010$ e $2173 / 2005$. In pratica, invece, l'attuazione dei principi del sistema di dovuta diligenza è in definitiva determinata dalle pratiche del mercato globale e dai sistemi globali, ad esse connesse, di valutazione della conformità che fanno riferimento alla legislazione forestale nazionale. 